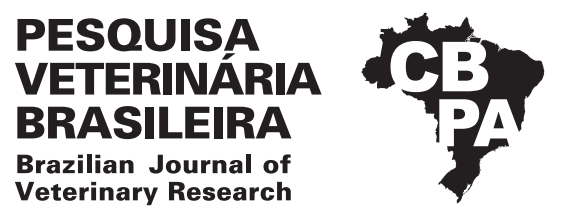

Pesq. Vet. Bras. 39(4):286-291, April 2019 DOI: 10.1590/1678-5150-PVB-5757

Original Article

Animal Morphophysiology

ISSN 0100-736X (Print)

ISSN 1678-5150 (Online)

\title{
Maternal, fetal and neonatal heart rate and heart rate variability in Holstein cattle ${ }^{1}$
}

\author{
Dario A.C. Quevedo ${ }^{2}$, Maria Lucia G. Lourenço ${ }^{3 *}$, Carmen D. Bolaños ${ }^{4}$, \\ Angélica Alfonso ${ }^{3}$, Carla M.V. Ulian ${ }^{3}$ and Simone B. Chiacchio ${ }^{3}$
}

\begin{abstract}
Quevedo D.A.C., Lourenço M.L.G., Bolaños C.D., Alfonso A., Ulian C.M.V. \& Chiacchio S.B. 2019. Maternal, fetal and neonatal heart rate and heart rate variability in Holstein cattle. Pesquisa Veterinária Brasileira 39(4):286-291. Faculdade de Medicina Veterinária e Zootecnia, Universidade Estadual Paulista "Julio de Mesquita Filho", Distrito Rubião Júnior s/n, Botucatu, SP 18618-970, Brazil. E-mail: maria-lucia.lourenco@unesp.br

The aim of this study was to describe the normal values for maternal, fetal and neonatal heart rate (HR) and heart rate variability (HRV) indexes in the time domain (standard deviation of beat-to-beat interval - SDNN; root mean square of successive beat-to-beat differences - RMSSD) and the frequency domain (low frequency - LF; high frequency - HF; relationship between low and high frequency - LF/HF) in 23 Holstein cows, 23 fetuses and 18 neonates during the perinatal period. HR and HRV were calculated by fetomaternal electrocardiography (ECG). Fetomaternal measurements were taken six times prepartum (between days 234 and 279 of pregnancy) and measurements were taken in neonates six times after calving (after birth and five times weekly). HR, time and frequency domain were analyzed. No significant changes in maternal, fetal beat-to-beat interval (RR interval) or HR were found. In maternal variables, SDNN decreased significantly from $38.08 \pm 2.6 \mathrm{~ms}$ (day 14 before calving) to $23.7 \pm 2.5 \mathrm{~ms}$ (day 1 after calving) $(\mathrm{p}<0.05)$, but the RMSSD did not change significantly. HR and RR interval of calf differed statistically from the day before delivery $(163 \pm 7.5 \mathrm{bpm} ; 381 \pm 24.2 \mathrm{~ms})$ to the day after calving $(131 \pm 5 \mathrm{bpm} ; 472 \pm 16.2 \mathrm{~ms})$. Time variables (SDNN and RMSSD) and the frequency-domain variables (LF and HF) were significantly different $(\mathrm{p}<0.05)$ between fetal and neonatal stages. Reductions in the values of SDNN and RMSSD can reflect a sympathetic dominance. After calving, the increase in HF and decrease in LF variables can indicate activation of the vagal nerve followed by heart and respiratory modulation.
\end{abstract}

INDEX TERMS: Maternal heart rate, fetal heart rate, neonatal, Holstein cattle, calf, electrocardiogram, cattle, morphology.

RESUMO.- [Frequência cardíaca e variabilidade da frequência cardíaca materna, fetal e neonatal em bovinos da raça Holstein.] 0 objetivo deste estudo foi descrever os valores normais para os índices de frequência cardíaca (FC) materna, fetal e neonatal e de variabilidade da frequência

\footnotetext{
${ }^{1}$ Received on May 18, 2018.

Accepted for publication on October 4, 2018.

${ }^{2}$ Departamento de Saúde Animal, Universidad de Nariño, Clle 18 Cr 50, Ciudadela Universitaria Torobajo, Pasto, Nariño, Colombia.

${ }^{3}$ Departamento de Clínica Veterinária, Faculdade de Medicina Veterinária e Zootecnia (FMVZ), Universidade Estadual Paulista "Julio de Mesquita Filho" (Unesp), Distrito Rubião Júnior, Botucatu, SP 18618-970, Brazil. *Corresponding author: maria-lucia.lourenco@unesp.br

${ }^{4}$ Departamento de Higiene Veterinária e Saúde Pública, Faculdade de Medicina Veterinária e Zootecnia (FMVZ), Universidade Estadual Paulista “Julio de Mesquita Filho" (Unesp), Distrito Rubião Júnior, Botucatu, SP 18618-970.
}

cardíaca (VFC) no domínio do tempo (desvio padrão do intervalo batimento a batimento, SDNN; raiz quadrada média de sucessivas diferenças de batimento a batimento, RMSSD) e do domínio da frequência (baixa frequência, LF; alta frequência, HF; relação entre baixa e alta frequência, LF/HF) em 23 vacas Holandesas, 23 fetos e 18 neonatos durante o período perinatal. A FC e a VFC foram calculadas por eletrocardiografia materno-fetal. As medidas materno-fetais foram realizadas seis vezes antes do parto (entre os dias 234 e 279 de gestação) as medidas neonatais foram realizadas seis vezes após o parto (um dia após nascimento e semanalmente, durante cinco semanas). FC, e variáveis no domínio do tempo e de frequência foram analisadas. Não foram encontradas alterações significativas na FC e no intervalo de batimento para batimento (intervalo RR) materno e fetal. Nas variáveis maternas, o SDNN diminuiu 
significativamente de $38,08 \pm 2,6 \mathrm{~ms}$ (dia 14 antes do parto) para $23,7 \pm 2,5 \mathrm{~ms}$ (dia 1 após o parto) ( $\mathrm{p}<0,05)$, mas o RMSSD não alterou significativamente. A FC e o intervalo e RR do bezerro diferiram estatisticamente a partir de um dia antes do parto $(163 \pm 7,5 \mathrm{bpm}, 381 \pm 24,2 \mathrm{~ms})$ até o dia seguinte ao parto (131 $\pm 5 \mathrm{bpm}, 472 \pm 16,2 \mathrm{~ms})$. As variáveis de tempo (SDNN e RMSSD) e as variáveis de domínio de frequência (LF e HF) foram significativamente diferentes $(\mathrm{p}<0,05)$ entre os momentos fetal e neonatal. As reduções nos valores de SDNN e RMSSD podem refletir domínio simpático. Após o parto, o aumento da HF e a diminuição das variáveis LF podem indicar a ativação do nervo vagal seguido de modulação cardíaca e respiratória.

TERMOS DE INDEXAÇÃO: Frequência cardíaca maternal, feto, neonatal, bovinos da raça Holstein, bezerro, eletrocardiograma materno-fetal, morfologia.

\section{INTRODUCTION}

Electrocardiography (ECG) has been proposed as a useful noninvasive technique for assessing well-being of the bovine fetus (Reef et al. 1996). Fetomaternal ECG allows continuous analysis of fetal and maternal heart rate (HR) and heart rate variability (HRV) which reflects sympathoadrenal activity in the late stages of pregnancy in cows and newborn calves. To improve perinatal care of cattle and reduce the mortality of newborns, especially for animals with high genetic value, ECG can be performed, and HR and HRV parameters can be measured. To date, there have been few studies of HR and HRV in cows and fetuses. Fetal heart rate (FHR) is the most frequently reported parameter used to assess fetal well-being in the final stages of pregnancy in humans, horses and sheep (Kovács et al. 2012, 2014a, 2014b).

Short-term fluctuations in HR are caused by modulation of cardiac action via the autonomous nervous system (Moberg 2000). HR represents the net interactions between vagal (which reduces HR) and sympathetic (which increases HR) regulation (Kleiger et al. 1995). A rise in HR is mainly caused by an increase in sympathetic activity, but it may also result from a decrease in vagal regulation or from simultaneous changes in both regulatory systems (Guyton \& Hall 2000). HRV analysis allows a much more accurate and detailed determination of the functional regulatory characteristics of the autonomic nervous system (ANS). HRV is a particularly good indicator for the noninvasive assessment of ANS activity in response to stress in farm animals (Von Borell et al. 2007). In human fetuses, short-term variability can be useful as an indirect indicator central nervous system function. It is based on the antagonistic oscillatory influences of the sympathetic and parasympathetic nervous system on the sinoatrial node (Van Leeuwen et al. 2007). HRV thus reflects the balance of sympathetic and parasympathetic tone in humans (Schneider et al. 2008). Reductions in the values of the HRV variables, standard deviation of beat-to-beat interval (SDNN) and root mean square of successive beat-to-beat differences (RMSSD) reflect a shift toward more sympathetic dominance, whereas increases indicate a shift toward parasympathetic dominance (Levy \& Martin 1978).

Power spectrum analysis has been employed to introduce a quantitative evaluation of the autonomic nervous system in the control of heart rate variability into clinical examinations in human adults and neonates (Malik et al. 1996). Spectral analysis of heart rate variability has potential as a noninvasive means to assess fetal autonomic nerve system activity and dynamic control in real time. Processes associated with autonomic nerve disorder can be detected through HR or blood pressure (Von Borell et al. 2007). The spectral analysis technique may provide us with a tool for the early detection of mutual imbalance between the two regulatory systems (Abboud \& Sadeh 1990). Low-frequency (LF nu) peaks in the spectral analysis of fetal heartbeat rate variability are associated with fetal sympathetic activity and partly with parasympathetic activity (Akselrod et al. 1981)

Studies have demonstrated the usefulness of the low frequency (LF)/high-frequency (HF) ratio of the power spectrum as an indicator of sympathetic activity (Abboud \& Sadeh 1990, Akselrod et al. 1981) with an increase in the $\mathrm{LF} / \mathrm{HF}$ ratio being interpreted as a regulatory shift toward sympathetic dominance. High vagal tone has been linked to efficient autonomic regulatory activity, which enables an organism to increase its sensitivity and response to physiological and environmental challenges.

Interpretation of FHR is complicated due to the multiple factors involved in its regulation: chemoreceptors, the sympathetic and parasympathetic nervous system, and fetal activity (Guyton \& Hall 2000). FHR not only enables verification of human fetal health and viability but also provides information about the stage of development of the autonomic nervous system (Camm et al. 1996). There is a need for clinical studies using fetal HRV measures under realistic conditions, and it is important to describe the normal ranges for such measurements. Thus, the aim of this study was to describe the normal values for maternal, fetal and neonatal HR and HRV indexes in the time domain (standard deviation of beat-to-beat interval, SDNN; root mean square of successive beat-to-beat differences, RMSSD) and the frequency domain (low frequency, LF; high frequency, HF; relationship between low and high frequency, LF/HF).

\section{MATERIALS AND METHODS}

Animals. The farm is located at an altitude of 804 meters above sea level, latitude $22^{\circ} 53^{\prime} 09^{\prime \prime} \mathrm{S}$ and longitude $48^{\circ} 26^{\prime} 42^{\prime \prime} \mathrm{W}$. The region has a humid subtropical climate. This project had the approval of the Ethics Committee on Animal Use - CEUA (No. 89-2014), and informed consent was given by the owner of the farm.

The 23 cows were selected from among the healthy, trouble-free specimens in the dry period stage. The exact day of pregnancy was calculated from reproductive records (artificial insemination or natural service) with pregnancy confirmation. From the beginning of the dry period, the animals were kept in a maternity paddock where they received corn silage three times a day. All of the cows were brought into an enclosed barn for sampling once a week. Two weeks prior to the start of the trial, the cows were acclimated to the facility and to the handling and electrocardiogram procedures.

Following birth, 17 clinically healthy and full-term-born Holstein calves (9 males and 8 females), were monitored. Heifer calves were removed from their mothers and transferred to individual pens. They received colostrum for the first 2 days and were then fed according to a regular schedule for rearing calves based on the provision of whole milk (milk offered twice a day, and liters calculated according to the weight of each animal), and gradual supplementation with concentrates. Bull calves were removed from their mothers 
and housed together, and they were fed with the same quantity of colostrum and ad libitum roughage (maize silage).

Experimental design. Fetomaternal ECG recordings were made between days 234 and 279 of pregnancy. Six recordings were conducted prepartum. Recordings were repeated at approximately 7-day intervals until 1 or 2 days before calving and one day after delivery. On each day, recordings were made for 7-10min, starting at 8 a.m. to 2 p.m. Neonatal recordings were made after birth and five times weekly. In cows as well as in fetuses and neonates, HRV was analyzed for a 5-min interval in the ECG recording. To remove trend components, the data were detrended, and artifact correction was performed using established procedures (Malik et al. 1996).

The electrocardiographic examinations were repeated at predefined times. Fetomaternal ECG was performed at six time points between day 35 and one or two days prepartum, resulting in 132 exams. Neonatal ECG was studied at six time points, from birth to 35 days of age; there were 108 recordings in total.

Maternal, fetal and neonatal ECG. Fetomaternal and neonatal ECG measurements were made with the Televet 100 recording system (version 4.2.3; Kruuse, Marslev, Denmark). After the cow entered the chute, 2 square inches of hair were shaved at the sites where the pads were to be attached with self-adhesive pads.

For all measurements, the green electrode was attached to the neck on the left side of the cow, $20 \mathrm{~cm}$ cranial from the point of the shoulder. The yellow electrode was placed in the flank region, above the line from the hip joint to the shoulder, and the black electrode was placed on the left croup. On the right side of the animal, the red electrode was attached to the abdomen at the height of the knee, along the line from the stifle joint to the point of the elbow. The electrodes were connected to the Televet 100 recording device. The Televet 100 sent the data via Bluetooth to a computer.

The Televet 100 uses a filter that can extract and amplify the fetal ECG signal from the abdominal ECG signal of the mother. The maternal signal represents a modified apex-base recording, and the fetal signal depends on fetal position in the uterus, so it is not a standardized recording.

For the neonates, the Televet 100 was fixed onto an elastic band around the thorax, and the electrodes were attached to the coat with self-adhesive pads. The red and black electrodes were placed on the right side of the lower part of the thorax, and the green and yellow electrodes were placed on the left side in the precordial region.

Heart rate variability analysis. Kubios HRV software (Biomedical Signal Analysis Group, Department of Applied Physics, University of Kuopio, Finland) was used for HRV analysis. In agreement with generally accepted recommendations for HRV analysis in animals (Tarvainen \& Niskanen 2008) a 5-min time interval of each recording was used to determine the HRV parameters. To remove trend components, the data were detrended, and an artifact correction was made. In the time domain, HR, beat-to-beat interval (RR), standard deviation of beat-to-beat interval (SDNN), and square root of the mean squared differences of successive RR intervals (RMSSD) were assessed. SDNN was used to reflect all cyclic components of the variability in recorded series of RR intervals. RMSSD was used as an estimate of high-frequency variations in short-term RR recordings. In the frequency domain (by fast Fourier transform analysis), the normalized power of the LF nu and the high-frequency band (HF nu) was calculated, as was the LF/HF quotient. LF Norm was used to examine sympathetic modulations, while HF Norm was used to evaluate parasympathetic modulations. LF/HF was used to assess sympathovagal balance. The divergent respiratory frequencies in calves and cows were taken into consideration by setting the limits of the $\mathrm{HF}$ band to $0.3 \mathrm{~Hz}$ (lower limit) and $0.8 \mathrm{~Hz}$ (upper limit) for calves, 0.25 and $0.58 \mathrm{~Hz}$ for cows (Von Borell et al. 2007).

Statistical analysis. Kolmogorov-Smirnov tests were used to assess normality of distribution for each variable. Normally distributed data were evaluated with 1-way ANOVA for repeated measures to analyze significant changes, and a post hoc Bonferroni test was performed for each HRV index at all time points. In addition, a paired t-test was used for the comparison of sampling stages with the first time point. The data that did not pass the Kolmogorov-Smirnov test were analyzed with nonparametric tests (Friedman analysis). The results are presented as the mean \pm SEM. A $p$ value $<0.05$ was considered significant. The SPSS statistical package (SPSS 21 Inc., Chicago/IL, USA) was used for data analyses.

\section{RESULTS}

Table 1 shows the mean, standard error of the mean $( \pm \mathrm{SEM})$ and range of the fetal and neonatal HR and the time-domain HRV indexes RR interval, SDNN, RMSSD at six time points before calving and six time points after delivery.

The HRV time-domain indexes SDNN and RMSSD and the frequency-domain variables LF nu and HF nu were significantly different from the fetal to the neonatal stage. FHR and RR intervals differed significantly from the neonatal stage at day one before calving ( $161 \pm 7.1$ beats/min $381 \pm 19.2 \mathrm{~ms})$ and the day after calving ( $130 \pm 4.8$ beats/min; $471 \pm 15.7 \mathrm{~ms})$ (Table 1). The change from the last day of gestation to the first day after calving was statistically significant $(p<0.05)$.

There was a significant change in RMSSD from the fetal to the neonatal stage, i.e., from the last day (day 1) before calving $(26.9 \pm 4.7 \mathrm{~ms})$ to one day after delivery $(29.2 \pm 7.3 \mathrm{~ms} ; p<0.05)$ (Fig.1). It was also observed a significant increase in the value of SDNN, from the day one before calving $(23.3 \pm 1.8 \mathrm{~ms})$ to the last day of the study (47.1 $\pm 9.8 \mathrm{~ms})$ (Table 1 ).

In the last month of gestation (days 244-279), the maternal mean SDNN reached a statistically significant change days 28 and 1 . It was also observed a significantly decreased in maternal SDNN from $38.08 \pm 2.6 \mathrm{~ms}$ (day 14 before calving) to $23.7 \pm 2.5 \mathrm{~ms}$ (day 1 after calving), whereas the variable RMSSD decreased without a significant difference (Fig.1).

The maternal RR interval decreased from gestational day 244 , with values of $849 \pm 105$ ms corresponding to an HR of $71 \pm 9 \mathrm{bpm}$, to the lowest RR intervals, observed 1 day before calving, with values of $781 \pm 149 \mathrm{~ms}$, corresponding to an HR of $78 \pm 12 \mathrm{bpm}$. Within 24 hours after delivery, the heart rate increased to $80 \pm 10 \mathrm{bpm}$. No significant changes in maternal RR interval or HR were found.

Table 2 contains the fetal and neonatal values for the frequency-domain components LF nu, HF nu and the ratio of $\mathrm{LF} / \mathrm{HF}$. There was a significant change in LF before $(41.1 \pm 9.6 \mathrm{nu})$ and after $(87.0 \pm 2.5 \mathrm{nu})$ calving and HF before $(79.2 \pm 4.6 \mathrm{nu})$ and after $(30.9 \pm 5.9 \mathrm{nu})$ delivery $(p<0.05)$. In the LF/HF ratio, there was no significant change seen in the transition from one stage to another.

Table 3 describes the results of recordings conducted at six time points during the 35 days before calving and one time point in the first 24 hours after calving in Holstein cows. The heart rate variability (HRV) indexes reported are in the time (HR, RR, SDNN and RMSSD) and frequency domains (LF, HF and LF/HF).

In the maternal frequency-domain indexes, LF and HF presented no statistically significant changes during the entire 

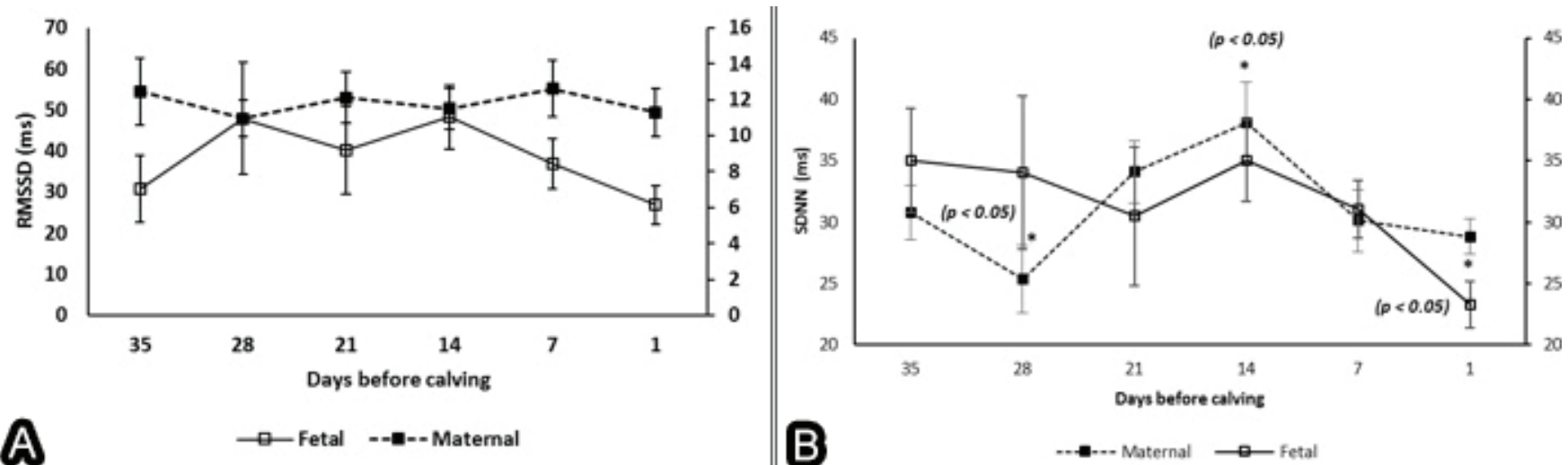

\section{A}

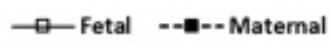

B

Fig.1. Maternal ( $\mathbf{\square}$ ) and fetal ( $\square$ ) heart rate variability in the time domain: (A) root mean square of successive beat-to-beat differences (RMSSD) and (B) standard deviation of the beat-to-beat interval (SDNN) at six time points from day 35 to 1 day before delivery ( $\mathrm{n}=16$ to 17 per time point).

Table 1. Mean \pm SEM and range of HRV indexes in the time domain during the perinatal period (n=16 to 18 per time point)

\begin{tabular}{|c|c|c|c|c|c|c|c|c|c|}
\hline & \multirow{2}{*}{ Day } & \multicolumn{2}{|c|}{ RR Interval (ms) } & \multicolumn{2}{|c|}{ Heart Rate (bpm) } & \multicolumn{2}{|c|}{ RMSSD (ms) } & \multicolumn{2}{|c|}{ SDNN (ms) } \\
\hline & & Mean \pm SEM & Range & Mean \pm SEM & Range & Mean \pm SEM & Range & Mean \pm SEM & Range \\
\hline \multirow{6}{*}{$\begin{array}{l}\text { Records } \\
\text { before } \\
\text { calving }\end{array}$} & -35 & $413 \pm 25.8^{\text {abc }}$ & 139 & $148 \pm 8.8^{\mathrm{bcd}}$ & 49 & $30.8 \pm 8.1^{\mathrm{ab}}$ & 44 & $35.1 \pm 4.2^{\mathrm{ab}}$ & 23 \\
\hline & -28 & $417 \pm 21.8^{\mathrm{abc}}$ & 160 & $147 \pm 8.1^{\mathrm{bcd}}$ & 60 & $47.9 \pm 13.4^{b}$ & 106 & $34.0 \pm 6.2^{\mathrm{ab}}$ & 52 \\
\hline & -21 & $407 \pm 21.6^{\mathrm{abc}}$ & 137 & $150 \pm 8.6^{\mathrm{bcd}}$ & 53 & $40.2 \pm 10.7^{\mathrm{ab}}$ & 62 & $30.5 \pm 5.6^{\mathrm{ab}}$ & 36 \\
\hline & -14 & $435 \pm 17.3^{\text {abcd }}$ & 135 & $139 \pm 5.8^{\mathrm{abcd}}$ & 47 & $48.2 \pm 7.8^{\mathrm{b}}$ & 67 & $35.0 \pm 3.3^{\mathrm{ab}}$ & 31 \\
\hline & -7 & $394 \pm 7.6^{\mathrm{ab}}$ & 77 & $153 \pm 2.9^{\text {cd }}$ & 30 & $37.0 \pm 6.1^{\mathrm{ab}}$ & 55 & $31.0 \pm 2.3^{\mathrm{ab}}$ & 24 \\
\hline & -1 & $381 \pm 19.2^{\mathrm{a}}$ & 264 & $161 \pm 7.1^{\mathrm{d}}$ & 98 & $26.9 \pm 4.7^{\mathrm{ab}}$ & 56 & $23.3 \pm 1.8^{\mathrm{a}}$ & 22 \\
\hline \multirow{6}{*}{$\begin{array}{l}\text { Records } \\
\text { after calving }\end{array}$} & 1 & $471 \pm 15.7^{\mathrm{bc}}$ & 260 & $130 \pm 4.8^{\mathrm{ab}}$ & 74 & $18.4 \pm 6.4^{\mathrm{a}}$ & 96 & $33.7 \pm 4.5^{\mathrm{ab}}$ & 79 \\
\hline & 7 & $441 \pm 14.9^{\text {cd }}$ & 256 & $139 \pm 5.0^{\mathrm{abcd}}$ & 88 & $18.1 \pm 6.1^{\mathrm{a}}$ & 85 & $32.7 \pm 4.6^{\mathrm{ab}}$ & 66 \\
\hline & 14 & $460 \pm 21.0^{\mathrm{abcd}}$ & 357 & $135 \pm 6.0^{\mathrm{abc}}$ & 109 & $21.4 \pm 4.5^{\mathrm{a}}$ & 67 & $33.5 \pm 4.2^{\mathrm{ab}}$ & 51 \\
\hline & 21 & $461 \pm 23.5^{\mathrm{bcd}}$ & 279 & $136 \pm 6.5^{\mathrm{abc}}$ & 76 & $16.6 \pm 5.5^{\mathrm{a}}$ & 88 & $37.9 \pm 7.5^{\mathrm{ab}}$ & 98 \\
\hline & 28 & $460 \pm 17.4^{\mathrm{bcd}}$ & 221 & $134 \pm 5.4^{\mathrm{abc}}$ & 72 & $23.8 \pm 7.0^{\mathrm{a}}$ & 85 & $35.4 \pm 6.1^{\mathrm{ab}}$ & 84 \\
\hline & 35 & $502 \pm 18.8^{\mathrm{d}}$ & 246 & $123 \pm 5.2^{\mathrm{a}}$ & 65 & $28.4 \pm 9.8^{\mathrm{ab}}$ & 128 & $47.1 \pm 9.8^{\mathrm{b}}$ & 125 \\
\hline
\end{tabular}

$\overline{a, b, c, d}$ Within each column, different superscripts denote significant differences $(\mathrm{p}<0.05)$; SEM = standard error of the mean, RR = beat-to-beat interval, RMSSD = root mean square of successive beat-to-beat differences, SDNN = standard deviation of beat-to-beat interval, $\mathrm{ms}=\mathrm{milliseconds}, \mathrm{bpm}=$ beats per minute. Bonferroni test.

Table 2. Mean \pm SEM and range of heart rate variability (HRV) indexes in the frequency domain during the perinatal period (n=16 to 18 per time point)

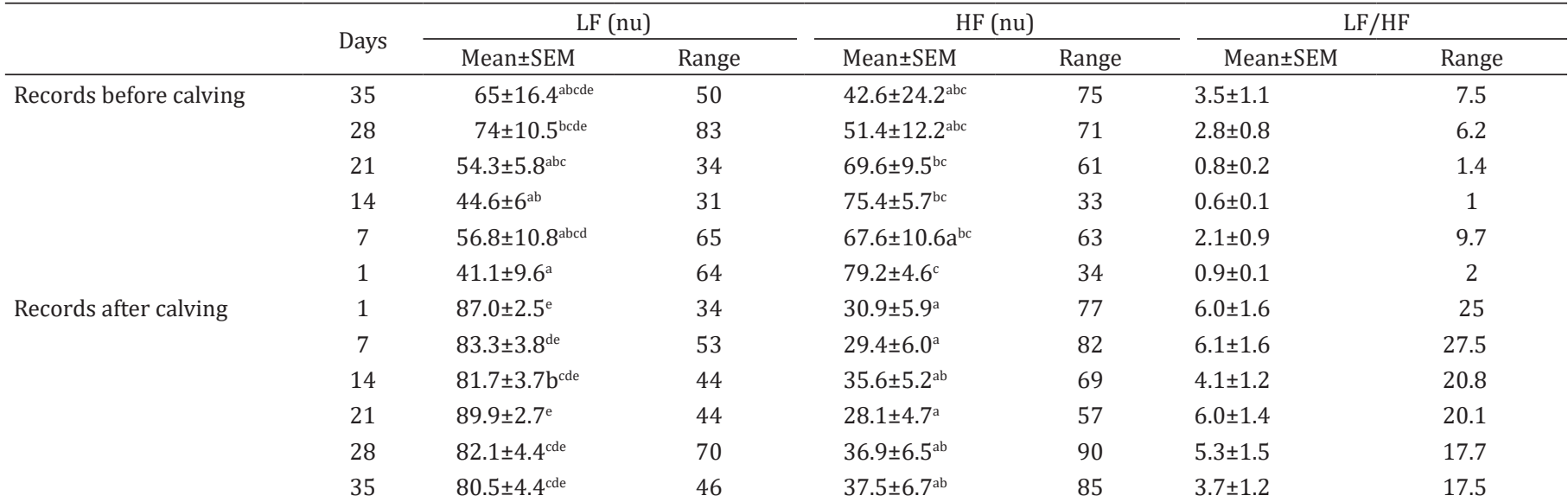

$\overline{a, b, c, d}$ Within each line, different superscripts denote significant differences $(\mathrm{p}<0.05)$; SEM = standard error of the mean, LH = low frequency, HF $=$ high frequency, $\mathrm{LF} / \mathrm{HF}=$ ratio of low frequency to high frequency, nu = normalized units. Bonferroni test. 
recording period before and after calving. Meanwhile, the LF/HF ratio had a statistically significant change $(p<0.05)$ on day $14(32.6 \pm 28.6)$ before calving and 24 hours after delivery

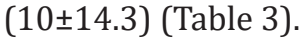

\section{DISCUSSION}

At day 35 before calving, the mean FHR was $148 \pm 8.8 \mathrm{bpm}$, and it exhibited a statistically significant increase to $161 \pm 7.1 \mathrm{bpm}$ by day 1 after delivery. During fetal life, there is a common increase in HR associated with the functional maturation of the cardiac muscle (Territo \& Altimiras 1998). After calving, neonatal HR decreased significantly to $130 \pm 4.8 \mathrm{bpm}$. After birth, HR tends to decrease with age due to structural and hemodynamic changes (Patteson 1996).

In the present study, the maternal HR increased from $71 \pm 8.9 \mathrm{bpm}$ to $80 \pm 3 \mathrm{bpm}$ and then decreased after delivery. During pregnancy, blood volume, heart rate and systolic volumen increase or increase the chronotropic overload to maintain homeostasis (Tejera et al. 2012). Thus, to supply a blood demand for the system, the autonomic nervous system will raise the heart rate (HR). This ability to adapt to different levels of stimuli is able to guarantee the safety of the autonomic nervous system (Kamath et al. 2013). The changes in maternal HR and RR interval during the days before delivery were not statistically significant, indicating that these parameters do not allow prediction of the delivery time.

In the fetal stage, recordings of RMSSD registered a statistically significant decrease from day 14 before calving, and SDNN decreased from day 35. Reductions in the values of the HRV variables SDNN and RMSSD reflect a shift toward greater sympathetic dominance (Aurich et al. 1993). Changes in fetal HRV observed during the last month of gestation indicate maturation of the ANS and its regulatory influence on HR.

After delivery, the neonates presented a declining trend in RMSSD and an increasing trend in SDNN, both statistically significant. These changes during the peripartum period suggest that calving is stressful for the fetus. Based on the amounts of catecholamines and endorphins released in calves, birth has been characterized as the most stressful event in their lifetime (Mohr et al. 2002).

Elevated HR values were observed in the first weeks of life of the neonate, suggesting increased sympathoadrenal activity in this period, presumably caused by increasing demands on the cardiovascular system with adaptation to extrauterine life (Nagel et al. 2012). Thus, sympathetic innervation could have rapidly increased the heart rate of these animals through the release of adrenal hormones, such as cortisol, through sympathetic stimulation of adrenal cortex cells (UlrichLai \& Herman 2009). The neonate has low blood pressure, blood volume and peripheral vascular resistance, so that, in order to maintain an adequate perfusion, it maintains a higher frequency and cardiac output, as well as central venous pressure compared to adults (Magrini 1978, Adelman \& Wright 1985).

In the fetal-stage recordings, an increase of LF normalized units and a decreased in HF normalized units until birth were registered, indicating sympathetic predominance during the active state in fetuses near full term. On the day before delivery, LF normalized units rose while HF normalized units declined, indicating modulation of heart rate and ventilation by the vagal nerve (Malik et al. 1996). In the neonatal stage, the low frequency in normalized units (LF nu) and high frequency in normalized units (HF nu) showed a stable behavior.

Weeks before calving, the RR interval dropped, corresponding to an increase in HR, in cows. The cardiovascular system of cows in advanced pregnancy thus adapts to the increasing demands of gestation with a rise in HR. Physiological HR in healthy, late-pregnant cows may therefore be slightly higher. The HRV time-domain index SDNN and frequency-domain index LF/HF ratio recorded a statistically significant decrease between day 1 before and day 1 after calving. The decline in the sympathovagal balance (LF/HF ratio) implies a dominance of cardiac sympathetic tone, which was also

Table 3. Mean \pm SEM heart rate variability (HRV) indexes in the time (HR, RR, SDNN and RMSSD) and frequency domains (LF, HF and LF/HF) during the last month of gestation and the first day after calving in Holstein cows (n=18 to 22 per time point)

\begin{tabular}{|c|c|c|c|c|c|c|c|c|}
\hline & \multirow{2}{*}{ Days } & \multicolumn{6}{|c|}{ Before calving } & \multirow{2}{*}{$\begin{array}{c}\text { After calving } \\
1 \\
\end{array}$} \\
\hline & & 35 & 28 & 21 & 14 & 7 & 1 & \\
\hline \multirow[t]{2}{*}{$\mathrm{LH} / \mathrm{HF}$} & Mean \pm SEM & $13.8 \pm 6.4^{\mathrm{ab}}$ & $19.7 \pm 5^{\mathrm{ab}}$ & $21.7 \pm 4.8^{\mathrm{ab}}$ & $32.6 \pm 4.5^{b}$ & $17.2 \pm 4.2^{\mathrm{ab}}$ & $15.6 \pm 4.1^{\mathrm{ab}}$ & $10.04 \pm 4.3^{\mathrm{a}}$ \\
\hline & Range & 28.8 & 44.8 & 60.5 & 106.5 & 62.4 & 67.6 & 61.4 \\
\hline \multirow[t]{2}{*}{$\mathrm{RR}$} & Mean \pm SEM & $849 \pm 37$ & $776 \pm 25$ & $783 \pm 29$ & $802 \pm 26$ & $790 \pm 18$ & $781 \pm 33$ & $749 \pm 21$ \\
\hline & Range & 347 & 312 & 324 & 409 & 259 & 519 & 321 \\
\hline \multirow[t]{2}{*}{ SDNN } & Mean \pm SEM & $30.7 \pm 3.7^{\mathrm{ab}}$ & $25.3 \pm 2.9^{\mathrm{a}}$ & $34 \pm 2.8^{\mathrm{ab}}$ & $38 \pm 2.6^{\mathrm{b}}$ & $30.7 \pm 3.7^{\mathrm{ab}}$ & $28.8 \pm 2.7^{\mathrm{ab}}$ & $23.7 \pm 2.5^{\mathrm{a}}$ \\
\hline & Range & 26.9 & 16.9 & 31.8 & 42.4 & 40.2 & 50.4 & 27.1 \\
\hline \multirow[t]{2}{*}{ HR } & Mean \pm SEM & $71 \pm 3$ & $78 \pm 3$ & $77 \pm 3$ & $76 \pm 2$ & $76 \pm 2$ & $80 \pm 3$ & $79 \pm 3$ \\
\hline & Range & 30 & 32 & 31 & 38 & 25 & 45 & 36 \\
\hline \multirow[t]{2}{*}{ RMSSD } & Mean \pm SEM & $12.4 \pm 1.7$ & $10.9 \pm 1$ & $12.1 \pm 1.4$ & $11.4 \pm 1.1$ & $11.7 \pm 1.3$ & $10.2 \pm 1.6$ & $13.9 \pm 1$ \\
\hline & Range & 13.1 & 11.3 & 17.1 & 17.2 & 23.3 & 24 & 28.7 \\
\hline \multirow[t]{2}{*}{ LF } & Mean \pm SEM & $92.1 \pm 2.7$ & $91.3 \pm 2.4$ & $91.6 \pm 2.2$ & $91.5 \pm 2.5$ & $87.9 \pm 3.7$ & $85.2 \pm 2.7$ & $79.9 \pm 3.5$ \\
\hline & Range & 23.5 & 31.7 & 30.4 & 38.5 & 55.2 & 39.7 & 41.5 \\
\hline \multirow[t]{2}{*}{$\mathrm{HF}$} & Mean \pm SEM & $9.3 \pm 2.9$ & $8.3 \pm 2.3$ & $8 \pm 2.1$ & $8.2 \pm 2.5$ & $14.6 \pm 3.7$ & $16.9 \pm 4.5$ & $19.8 \pm 3.5$ \\
\hline & Range & 21.9 & 30.7 & 29.4 & 38.5 & 54.6 & 89.1 & 41.5 \\
\hline
\end{tabular}

a, b Within each line, different superscripts denote significant differences ( $\mathrm{p}<0.05)$; SEM = standard error of the mean, RR = beat-to-beat interval, RMSSD = root mean square of successive beat-to-beat differences, SDNN = standard deviation of beat-to-beat interval, ms = milliseconds, BPM = beats per minute, $\mathrm{LH}=$ low frequency, $\mathrm{HF}=$ high frequency, $\mathrm{LF} / \mathrm{HF}=$ ratio of low frequency to high frequency, nu = normalized units. Bonferroni test. 
observed in lactating dairy cows by Kovács et al. 2014b. Changes in HRV with a declining trend in the last day might be associated with stressful situations (Schmidt et al. 2010). This study demonstrates that cows give birth under reduced parasympathetic tone.

\section{CONCLUSIONS}

Frequency heart rate (FHR) monitoring not only makes it possible to assess fetal health and viability but also can suggest information about the stage of development of the ANS. Reductions in the values of SDNN and RMSSD can reflect a shift toward greater sympathetic dominance.

After calving, the increase in HF and decrease in LF variables can indicate activation of the vagal nerve followed by heart and respiratory modulation.

Acknowledgements. The authors wish to acknowledge the assistance of all who contributed to this paper and, in particular, the owner of the farm, which allowed the use of his animals in this study.

Conflict of interest statement- The authors have no competing interests.

\section{REFERENCES}

Abboud S. \& Sadeh D. 1990. Power spectrum analysis of fetal heart rate variability using the abdominal maternal electrocardiogram. J. Biomed. Eng. 12(2):161-164. <http://dx.doi.org/10.1016/0141-5425(90)90138-D> <PMid:2319767>

Adelman R.D. \& Wright J. 1985. Systolic blood pressure and heart rate in the growing beagle puppy. Dev. Pharmacol. Ther. 8(6):396-401. <http:// dx.doi.org/10.1159/000457064><PMid:4075938>

Akselrod S., Gordon D., Ubel F.A., Shannon D.C., Berger A.C. \& Cohen R.J. 1981. Power spectrum analysis of heart rate fluctuation: a quantitative probe of beat-to-beat cardiovascular control. Science 213(4504):220-222. <http:// dx.doi.org/10.1126/science.6166045> <PMid:6166045>

Aurich J.E., Dobrinski I., Petersen A., Grunert E., Rausch W.D. \& Chan W.W. 1993. Influence of labor and neonatal hypoxia on sympathoadrenal activation and methionine enkephalin release in calves. Am. J. Vet. Res. 54(8):1333-1338. <PMid:8214906>

Camm A.J., Malik M. \& Bigger J.T. 1996. Heart rate variability: standards of measurement, physiological interpretation and clinical use. Task force of the european society of cardiology and the North American society of pacing and electrophysiology. Circulation 93(5):1043-1065. <http:// dx.doi.org/10.1161/01.CIR.93.5.1043><PMid:8598068>

Guyton A.C. \& Hall J.E. 2000. The heart, p.95-142. In: Guyton A.C. \& Hall J.E. (Eds), Textbook of Medical Physiology. 10th ed. W.B. Saunders, Philadelphia.

Kamath M., Watanabe M. \& Upton A. 2013. Heart Rate Variability Signal Analysis: clinical applications. CRC Press, New York. p.532.

Kleiger R.E., Stein P.K., Bosner M.S. \& Rottman J.N. 1995. Time domain measurements of heart rate variability, p.33-45. In: Malik M. \& Camm A.J. (Eds), Heart Rate Variability. Futura Publishing Company Inc, Armonk, New York.

Kovács L., Krisztina N., Szelényi Z., Szenci O. \& Janos T. 2012. Heart rate variability as a measure of stress in cattle: biological background, methods of measurement and results, a review. Magyar Allatorvosok Lapja 134:515-523.

Kovács L., Jurkovich V., Bakony M., Szenci O., Poti P. \& Tozser J. 2014a. Welfare implication of measuring heart rate and heart rate variability in dairy cattle: literature review and conclusions for future research. Animal 8(2):316-330. <http://dx.doi.org/10.1017/S1751731113002140> <PMid:24308850>

Kovács L., Tozser J., Szenci O., Poti P., Kezer F.L., Ruff F., Gabriel-Tozser G., Hoffmann D., Bakony M. \& Jurkovich V. 2014b. Cardiac responses to palpation per rectum in lactating and nonlactating dairy cows. J. Dairy
Sci. 97(11):6955-6963. <http://dx.doi.org/10.3168/jds.2014-8327> $<$ PMid:25200771>

Levy M.N. \& Martin P.J. 1978. Neural control of the heart, p.337-354. In: Berne R.M. (Ed), Handbook of Physiology. American Physiological Society, Rockville.

Magrini F. 1978. Haemodynamic determinants of the arterial blood pressure rise during growth in conscious puppies. Cardiovasc. Res. 12(7):422-428. <http://dx.doi.org/10.1093/cvr/12.7.422><PMid:719655>

Malik M., Camm A.J., Bigger J.T., Breithar D.T., Cerutti S., Cohen R.J., Coumel P., Fallen E.L., Kennedy H.L., Kleiger R.E., Lombardi F., Malliani A., Moss A.J., Rottman J.N., Schmidt G., Schwartz P.J. \& Singer D.H. 1996. Heart rate variability: standards of measurement, physiological interpretation, and clinical use. Eur. Heart J. 17(3):354-381. <http://dx.doi.org/10.1093/ oxfordjournals.eurheartj.a014868 > <PMid:8737210>

Moberg G.P. 2000. Biological response to stress: implications for animal welfare, p.1-21. In: Moberg G.P., Mench J.A. (Eds), The Biology of Animal Stress. CABI Publishing Wallingford, United Kingdom. <http://dx.doi org/10.1079/9780851993591.0001>

Mohr E., Langbein J. \& Nurnberg G. 2002. Heart rate variability: a noninvasive approach to measure stress in calves and cows. Physiol. Behav. 75(1/2):251-259. <http://dx.doi.org/10.1016/S0031-9384(01)00651-5><PMid:11890975>

Nagel C., Erber R., Bergmaier C., Wulf M., Aurich J., Möstl E. \& Aurich C. 2012. Cortisol and progestin release, heart rate and heart rate variability in the pregnant and postpartum mare, fetus and newborn foal. Theriogenology 78(4):759-767.<http://dx.doi.org/10.1016/j.theriogenology.2012.03.023> $<$ PMid:22626780>

Patteson M. 1996. Equine Cardiology. Oxford e Northampton, Blackwell Science, England. p.254.

Reef V.B., Vaala W.E., Worth L.T., Sertich P.L. \& Spencer P.A. 1996. Ultrasonographic assessment of fetal well-being during late gestation: development of an equine biophysical profile. Equine Vet. J. 28(3):200-208. <http://dx.doi. org/10.1111/j.2042-3306.1996.tb03773.x><PMid:28976710>

Schmidt A., Mostl E., Wehnert C., Aurich J., Muller J. \& Aurich C. 2010. Cortisol release and heart rate variability in horses during road transport. Horm. Behav. 57(2):209-215. <http://dx.doi.org/10.1016/j.yhbeh.2009.11.003> <PMid:19944105>

Schneider U., Frank B., Fiedler A., Kaehler C., Hoyer D., Liehr M., Haueisen J. \& Schleussner E. 2008. Human fetal heart rate variability-characteristics of autonomic regulation in the third trimester of gestation. J. Perinatal Med. 36(5):433-441. <http://dx.doi.org/10.1515/JPM.2008.059> $<$ PMid:18605969>

Tarvainen M.P. \& Niskanen J.P. 2008. Kubios HRV Version 2.0. User's Guide. Department of Physics, University of Kuopio, Kuopio, Finland.

Tejera E., Areias J.M., Rodrigues A., Nieto-Villar J.M. \& Rebelo I. 2012. Blood pressure and heart rate variability complexity in normal pregnancy. Influence of age, familiar history and parity. Hypertension Pregnancy 31:91-106. <http://dx.doi.org/10.3109/10641955.2010.544801><PMid:21599453>

Territo P.R. \& Altimiras J. 1998. The ontogeny of cardio-respiratory function under chronically altered gas compositions in Xenopus laevis. Respiratory Physiol.111(3):311-323.<http://dx.doi.org/10.1016/S0034-5687(97)001175><PMid:9628236>

UlrichLai Y.M. \& Herman J. 2009. Neural regulation of endocrine and autonomic stress response. Nat. Rev. Neurol. 10:307-409.

Van Leeuwen P., Lange S., Geue D. \& Gronemeyer D. 2007. Heart rate variability in the fetus: a comparison of measures. Biomed. Tech., Berlin, 52(1):61-65 <http://dx.doi.org/10.1515/BMT.2007.012><PMid:17313336>

Von Borell E., Langbein J., Despres G., Hansen S., Leterrier C., Marchant-Forde J., Marchant-Forde R., Minero M., Mohr E., Prunier A., Valance D. \& Veissier I. 2007. Heart rate variability as a measure of autonomic regulation of cardiac activity for assessing stress and welfare in farm animals, a review. Physiol. Behav. 92(3):293-316. <http://dx.doi.org/10.1016/j.physbeh.2007.01.007> $<$ PMid:17320122> 